\title{
JUSTIFICATION FOR 80 PSI RAILROAD \\ DOOR SEALING PRESSURE
}

R. H. Larson

\section{DISCLAIMER}

This report was prepared as an account of work sponsored by an agency of the United States Government. Neither the United States Government nor any agency thereof, nor any of their employees, makes any warranty, express or implied, or assumes any legal liability or responsibility for the accuracy, completeness, or usefulness of any information, apparatus, product, or process disclosed, or represents that its use would not infringe privately owned rights. Reference herein to any specific commercial product, process, or service by trade name, trademark, manufacturer, or otherwise does not necessarily constitute or imply its endorsement, recommendation, or favoring by the United States Government or any agency thereof. The views and opinions of authors expressed herein do not necessarily state or reflect those of the United States Government or any agency thereof.

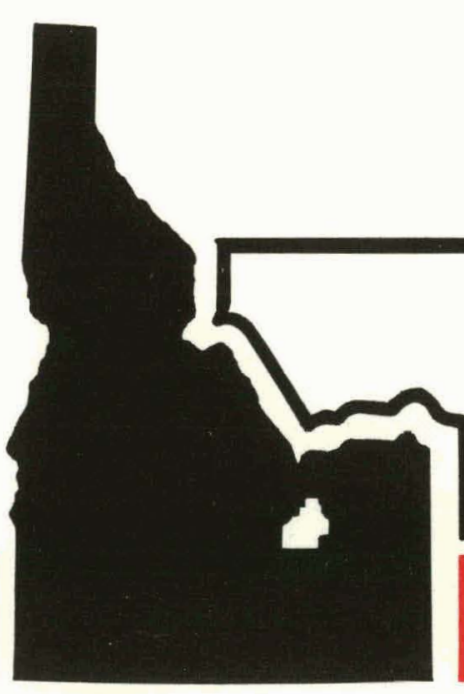

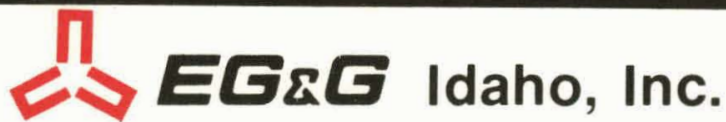

IDAHO NATIONAL ENGINEERING LABORATORY

\section{DEPARTMENT OF ENERGY}

IDAHO OPERATIONS OFFICE UNDER CONTRACT EY-76-C-07-1570 


\section{DISCLAIMER}

This report was prepared as an account of work sponsored by an agency of the United States Government. Neither the United States Government nor any agency Thereof, nor any of their employees, makes any warranty, express or implied, or assumes any legal liability or responsibility for the accuracy, completeness, or usefulness of any information, apparatus, product, or process disclosed, or represents that its use would not infringe privately owned rights. Reference herein to any specific commercial product, process, or service by trade name, trademark, manufacturer, or otherwise does not necessarily constitute or imply its endorsement, recommendation, or favoring by the United States Government or any agency thereof. The views and opinions of authors expressed herein do not necessarily state or reflect those of the United States Government or any agency thereof. 


\section{DISCLAIMER}

Portions of this document may be illegible in electronic image products. Images are produced from the best available original document. 


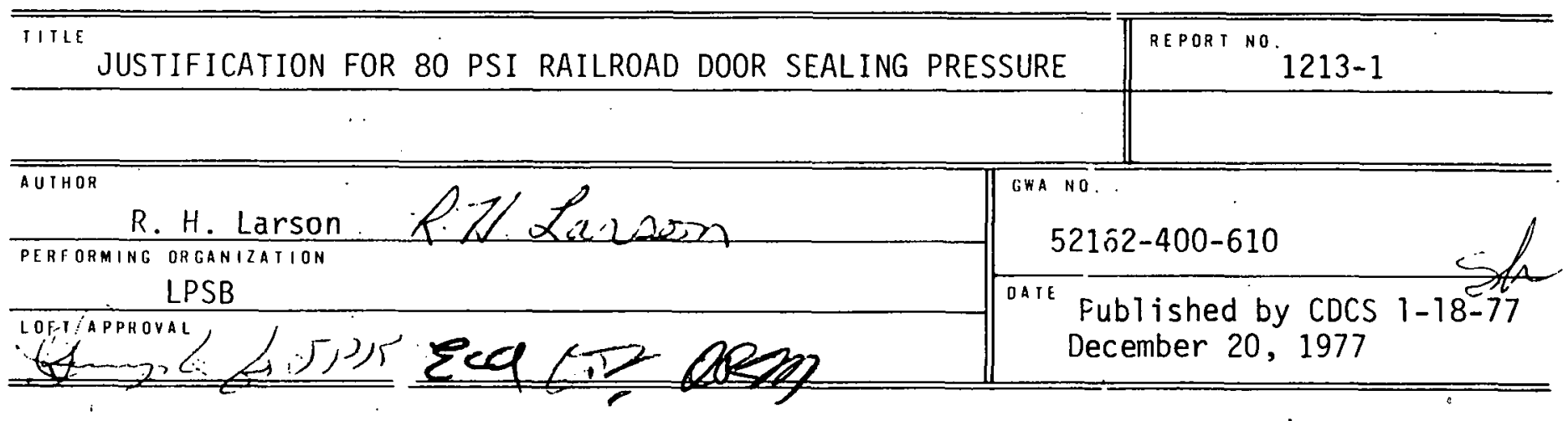

\section{INTRODUCTION}

The normal operating pressure for the inner and outer Rail Road Door Seals is $90 \mathrm{psig}$. The instrumentation which monitors this pressure does not provide assurance that the 90 psig can be maintained during reaitor operations. A decrease in pressure is detected by a low Tevel pressure alarm set to alarm at 88 psig. When another 8 psig is allowed for the instrument error of this alarm and the operating band during the leak test, the minimum pressure maintained in the seals is reduced to $80 \mathrm{psig} .80 \mathrm{psig}$, therefore, is the pressure that the LOFT Technical Specifications have committed to maintain.

\section{BASIS}

To provide justification for the 80 psig sealing pressure, a leak test was performed at $80+\frac{2}{0}$ pig. (Previous tests were performed at the normal operating pressure of $90 \mathrm{psig.)}$ The leak rate through the seals at. $80 \pm 2$ psig was $3.188 \times 10^{-4}$ $\mathrm{f} /$ day. A previous leak test at $90 \pm 2$ psig determined a leak rate through the Railroad Door Seals of $2.596 \times 10^{-4} \mathrm{f} /$ day. The requirement for acceptance for this test is that all the individial nenetration Leak Rates combined be $<12 \times 10^{-4} \mathrm{f} /$ day. Using the Leak Rate with the Railroad Seals pressurized to $80 \pm 2$, the combined leakage for all penetrations is $10.151 \times 10^{-4} \mathrm{f} /$ day which is $85 \%$ of the acceptance Timit. (See Attachment 1)

If, in the future, it becomes necessary to reduce the Leak Rate through the Railroad Door Seals, the operating pressure can be increased to 95 psig, the low level alarm can be increased to $93 \mathrm{psig}$, and the pressure committed to be maintained by the LOFT Technical Specifications can be increased to 85 psig. (See Attachment 2) 
Yutil Hu. I)(1)! $1 \ldots 001$

Havillall Nin.

itil.

Railroad Door Seals Leak Test

Champesi in ellect:

l'artal or $1: 111,1$ $X$ I:curet.

l'est completed December 11, 1977

linclosiule: :

Irest Summary

Te:at: Deflelencles

Conclustons and recommendathons

vata blicets Included Xeis $X$ No

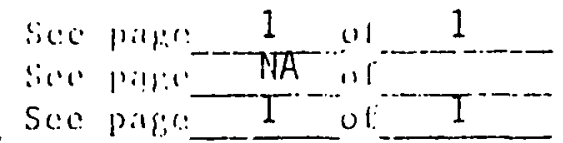
u No

c.uk(s) 1ssued

Ycs; No $x$

1. Test Summary

The railroad doors were tested for leakage of the seals arinulus at a seal pressure of $80^{\circ} \mathrm{psig}-0 \mathrm{psi}$. The annulus leak rate was determined to be $3.188 \times 18^{-4} \mathrm{f} /$ day. The acceptance limit for this component of the containment is $3.12 \times 10 \mathrm{f} /$ day.

2. Conclusions and Recommendations

It is recommended that the measured leak rate be accepted. This recommendation is based on a comparison with the results of S0-45.01. In this previous test the seals were pressurized to $90 \pm 2$ psig and resulted in an annuius leakage rate of $2.596 \times 10^{-4} \mathrm{f} /$ day. This leakage gave an overall containment leakage of $9.569 \times 10^{-4}$ $\mathrm{f} /$ day which was $79.7 \%$ of the acceptance 1 imit of $12 \times 10^{-4} \mathrm{f} /$ day. Using the annulus leak rate measured in this test gives an overall containment leakage of $10.161 \mathrm{f} /$ day or $84.7 \%$ of the overali containment acceptarce limit.

Approved by:

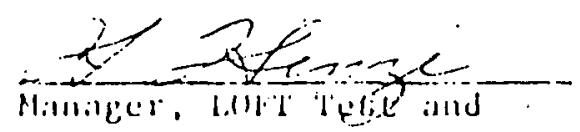

Data Branch

Iaveed by LOLI CDCS

Date

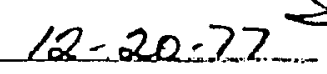

l'repareal by:
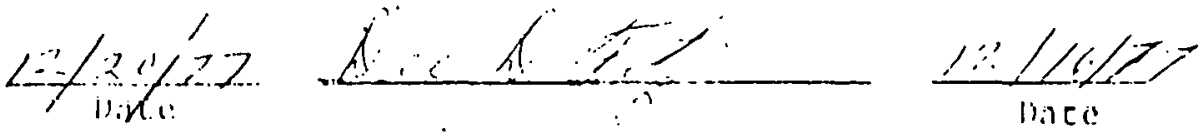


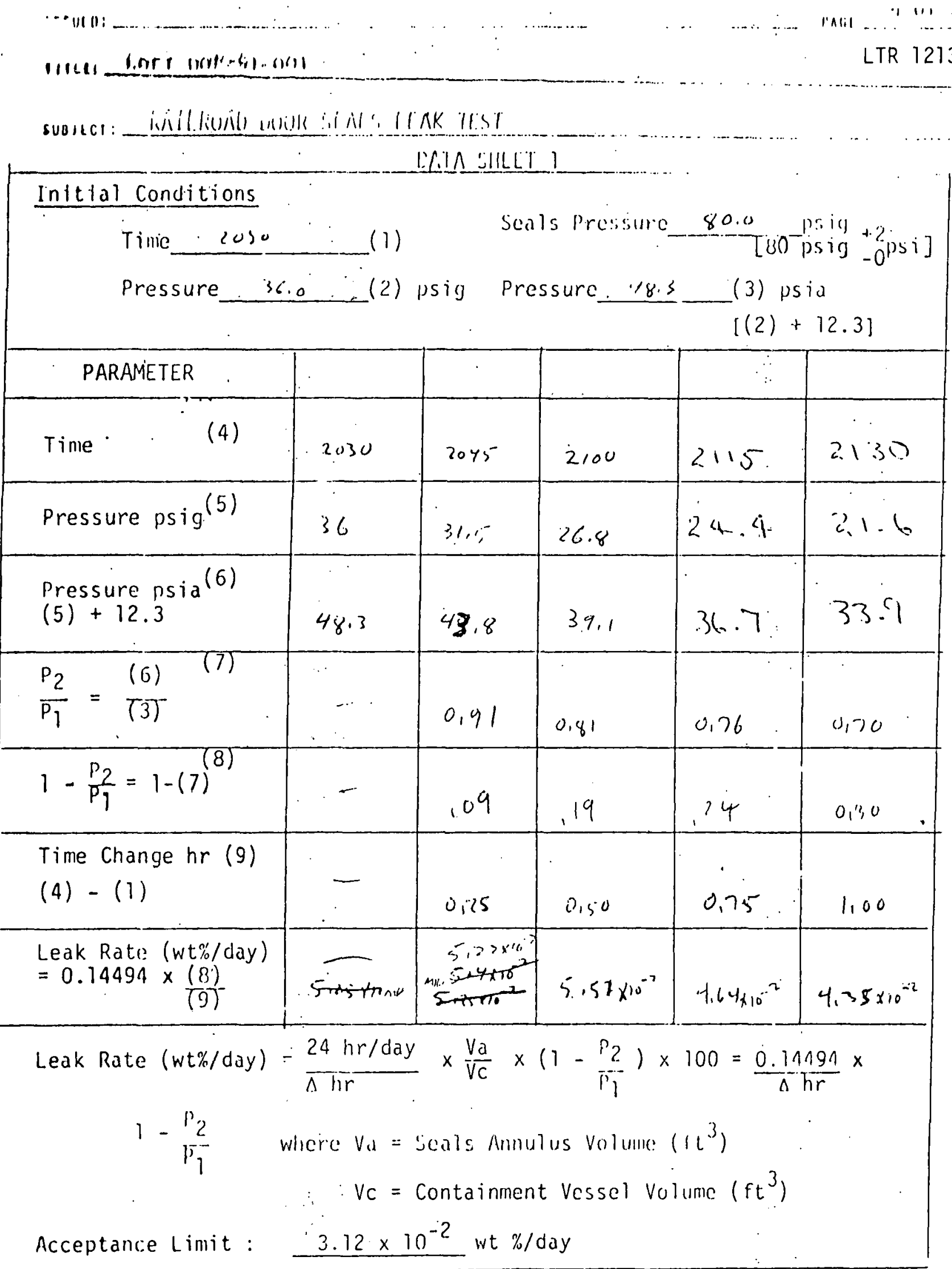

Original Issue

Date: 5-12-77 


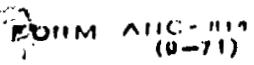

Issurgo:

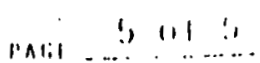

HiLe: LOIT 1001-50-0011

SUBHECI: RAIL.RONO DOOOR SLIN.S LLAK TIS:II

DATA SHEET 1. (con' $l)$

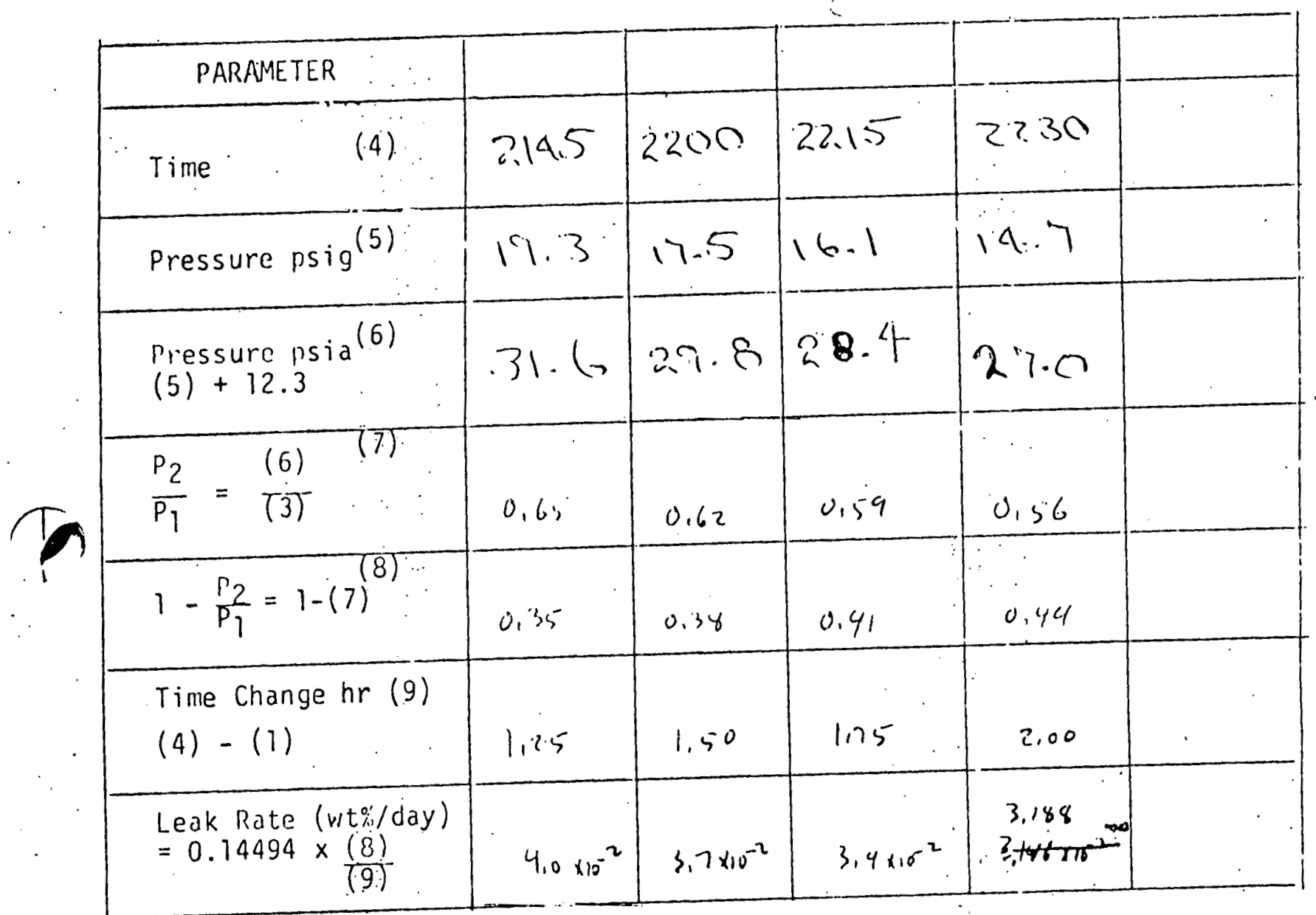

original Issue

Date: $5-12-77$ 


\section{PRESRAY}

PAWLING. NEW YORK 12564

(?14) H\$! 1220

January 10,1978

EG\&G Idaho, Inc.

P.O. Box 1625

Idaho Falls, Idaho 83401

Attention: 'Mr. David J. Shlmeck, Project Manglger

Subject: $\quad$ LOFT Rallroad Door Seals

Reference: $\quad$ Presray FO 11722

Dear Mr. Shimeck:

In answer to your letter of December 14 th there is an adequate design safety margin to increase the seal operating pressure to 95 psig.

$\mathrm{TCH} /$ amc

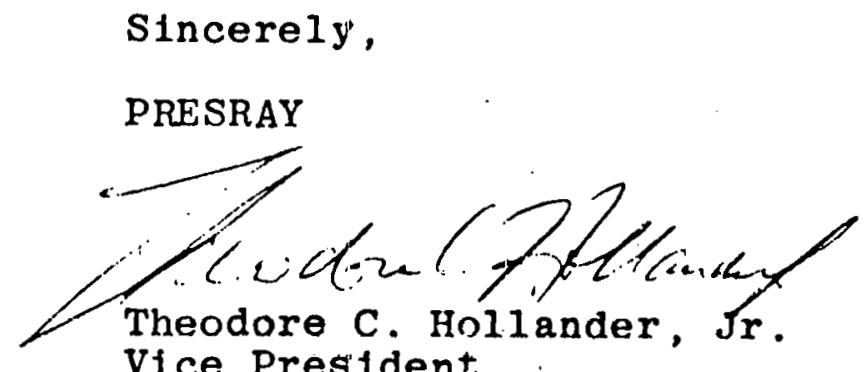

